\title{
TransELTE2021 - OFFI Akadémia XXIII. Fordítástudományi Konferencia
}

\section{(Második nap, online konferencia, 2021. március 25-26).}

\author{
Szentirmay Piroska \\ E-mail: szentirmay.piroska@gmail.com
}

Az ELTE Fordító- és Tolmácsképző Tanszékének és az Országos Fordító és Fordításhitelesítő Irodának 23 éve tartó közös konferenciasorozatában a második napot hagyományosan az Országos Fordító és Fordításhitelesítő Iroda (OFFI) rendezte, a járványhelyzetre való tekintettel már második alkalommal online formában. A konferenciát Németh Gabriella, az OFFI Zrt. vezérigazgatója nyitotta meg. Feladatellátási nehézségek és kihívások az OFFI évtizedeiből címü elöadásában betekintést nyújtott a fordítóiroda múltjába a válság szemszögéböl nézve. A történeti visszatekintés tanulsága, hogy a fordítóirodának mindig meg kellett küzdenie újabb és újabb kihívásokkal, melyek ellenére a munka immár több mint másfél évszázada folyamatosan folyik, a válságálló OFFI magabiztosan alakítja új, hosszú távú stratégiáját, hogy a jövő kihívásainak is sikerrel feleljen majd meg.

Az első plenáris előadást Láncos Petra, a Pázmány Péter Katolikus Egyetem, Jog- és Államtudományi Kar docense tartotta Tolmácsolás az Európai Unió Bíróságán a pandémia idején címmel. Kérdőíves felmérés eredményein keresztül mutatta be azoknak a tolmácsoknak a tapasztalatait, akik az Európai Unió Bíróságán dolgoznak. Az aktuális járványhelyzet miatt a tárgyalások lebonyolítása érdekében új egészségügyi intézkedésekhez kell alkalmazkodni, ami többlet terhet jelent a szinkrontolmácsok számára is, akik új stratégiák kialakításával igyekeznek rugalmasan alkalmazkodni a szokatlan feltételekhez mind a felkészülésben, mind a kabinban a tolmácsok közötti együttmüködésben mind a technológiai eszközök használatában.

A második plenáris előadás két előadója, Natascia Ralli és Klare Kranebitter, a bolzanoi EURAC Alkalmazott Nyelvészti Kutatóintézet képviseletében beszélt a terminusok járványszerű terjedéséről a COVID 19 pandémia idején. Bemutatták, hogy a jelenség miként volt érzékelhető az EURAC bistro elnevezésü jogi terminológiai informatikai rendszerben. A világjárvány miatt egy speciális szókincs jelent meg a hétköznapokban, hiszen a betegséggel kapcsolatosan új terminusok

Hivatkozás: Szentirmay P. 2021. TransELTE2021 - OFFI Akadémia XXIII. Fordítástudományi Konferencia (Második nap, online konferencia, 2021. március 25-26). Fordítástudomány 23. évf. 1. szám. 117-119. DOI: https://doi.org/10.35924/fordtud.23.1.10 
és fogalmak születtek. Ez az új, kreatív terminológia nemcsak az egészségügyet, hanem a jog, a gazdaság és az élet számos más területét is érinti. A vészhelyzet folyamatos változása miatt a terminológiai állomány is nagyon gyorsan változik. A kutatóintézet ezért 2020 márciusa óta dolgozik egy naprakész Covid-19 terminológiai adatbázis megteremtésén, melyet a közigazgatás számára Trentino-Alto Adige régió három hivatalos nyelvén, olasz, német és ladin nyelveken tesznek elérhetővé a felhasználók számára.

A koronavírus-járvány idején Magyarországon is folyik terminológiai munka, melyről Papp Eszter, Somogyi Zoltán és Szemők Ildikó terminológusok számoltak be Forditásorientált terminológia és minöségellenörzés a Covid1001 önkéntes szakforditói csoportban címủ előadásukban. A COVID1001 önkéntes szakfordítói csoport azzal a céllal alakult meg egy évvel ezelőtt, hogy a nagy számban megjelenő nemzetközi publikációkat és dokumentumokat magyar nyelven is elérhetővé tegye az orvosszakma számára, ezzel is segítve a koronavírus elleni küzdelmet. A csoport másodlagos célja ismeretterjesztő cikkek fordítása a szélesebb nagyközönség számára. A kb. 100 aktív tagot tömörítő munkacsoportban a fordításipar és az egészségügy szakemberei járulnak hozzá a Memoq szerveren folyó munkához. A csoport adatbázisának memóriájában immár kb. 170 cikk és egymillió szövegszó található. A fordítási, lektorálási munkát a Memoq beépített QA funkciói, valamint külső QA eszközök is segítik.

Szoták Szilvia az OFFI Zrt. lektorátusvezetője Minőségbiztositási alapelvek a nyelvi közvetitésben: az ISO17100-tól az ISO 18841-ig címmel mutatta be a nyelvi szolgáltatás komplex folyamatát, melynek minden fázisában megjelenik a minőségbiztosítás, meghatározva minden résztvevő szakember munkáját. A minőségbiztosítással kapcsolatos kihívások jelentős változáson mentek át az elmúlt évtizedekben, ma már az ISO szabványok követelményei a meghatározók, teljesítésük növeli a szervezet működési hatékonyságát és biztosítja az egységesen magas minőségü szolgáltatást. Az OFFI-ban a minőségbiztosítás eszközei a megfelelő munkatárs kiválasztásán túl a megfelelő fordítási környezet használata, a technológiai és nyelvi tudatosság fejlesztése, a lektorálás, valamint olyan informatikai megoldások, mint fordítómemóriák, terminológiai adatbázisok és rendszerbe épített informatikai eszközök alkalmazása.

A plenáris előadásokat követően $A$ hiteles forditás szakmai kihívásai és módszertana címet viselö blokkban az OFFI Lektori Mühelyének munkájába kaptak betekintést az érdeklődők. Az előadók számos érdekes példán keresztül mutatták be azokat a fordítási nehézségeket, melyek mind nyelvi, mind fogalmi szinten fordítói döntéseket, jogszabályokra épülő fordítói stratégiák kidolgozását teszik szükségessé az okiratok hiteles fordítása során. Boronkay-Roe Zsuzsanna az oktatással kapcsolatos angol nyelvü okiratok fordításáról, Csányi-Siffel Enikő az olasz nyelvű okiratfordítások megoldásairól beszélt, Dihen Judit a magyar és a német nyelvű anyakönyvi kivonatok hiteles fordításának kérdéseit, és végül Pablényi Magdolna a francia okiratfordítások egyes típusaiban jelentkező fordítói kihívásokat mutatta be. 
A Lektori Mühely munkájának ismertetése után következett az a kerekasztal beszélgetés, ami $A$ hiteles forditás technológiai támogatása címet kapta. Tamás Dóra Mária, Polácska Edina, Klenk Márk, Kántor Ákos elemezték a nyelvtechnológiai kihívásokat a hiteles fordításokban, rávilágítva arra, hogy a fordítási projektfolyamat elején nem a fordító áll, mivel a tényleges fordítói munka elökészítése külön szakmai felkészültséget és munkakapacitást igényel a fordítóirodától. A beérkező dokumentumokat fordításra elő kell készíteni, majd a kész fordítás is igényel utólagos szerkesztési munkálatokat. Ez az összetett csapatmunka biztosítja a projektek minél rövidebb átfutási idejét és a megrendelö felé nyújtott szolgáltatás magas minőségét.

Az OFFI-hoz hasonlóan müködik a Kanadai Kormány Fordítási Irodája. A Terminológiai Divízió képviseletében Mélanie Labelle terminológus Terminológia a válság idején: forditóirodánk szójegyzéke a COVID19 járványról (TermiumPlus terminológiai adatbázis) címü előadásában mutatta be a fordítóiroda munkáját, a világjárványhoz kapcsolódó szójegyzék összeállításának hátterét és annak fejlődését, tartalmát, hogy milyen típusú terminusok szerepelnek benne, milyen témabeosztás szerint dolgoztak és milyen típusú információkat találnak meg a felhasználók az egyes szócikkekben. Előadásában kitért az alkalmazott módszerekre, valamint azokra a kihívásokra, melyekkel a munka során találkoztak. Egy konkrét fordítási problémán keresztül szemléltette, hogy a pandémia alatt milyen gyorsan változott a valóság, mely tükröződött a terminológia változásában is, és egy példát is hozott arra, hogy egy fogalom megnevezése miként változott a világjárvány eddigi 12 hónapja alatt.

A gazdag konferenciaprogramot $A$ hiteles forditás mint közfeladat címü kötet bemutatása zárta. A könyvet Fischer Márta, a BME Idegen Nyelvi Központ igazgatója ismertette. A szakmai kiadvány az OFFI kiadványsorozatának legújabb tagja, szerkesztője Szoták Szilvia. A kötetben az OFFI vezetői, lektorai és munkatársai példákkal szemléltetve osztják meg szakmai munkájuk tanulságait, hogyan kapcsolódik össze a gyakorlat az elmélettel, kitérve nemcsak a fordítási folyamatokra, hanem a fordítás eredményére, a fordítóiroda múltjára, jelenére és a jövő kihívásaira is. A kötet néhány fejezete már megtalálható az OFFI honlapján az ingyenesen elérhető kiadványok közt. 